\title{
VALUES AND ANTI-VALUES IN FIGURATIVE PHRASEOLOGICAL UNITS IN THE RUSSIAN AND GERMAN LANGUAGES
}

Yelena Anatolyevna Andreyeva ${ }^{1 *}$, Inna Germanovna Korneva ${ }^{2}$, Kadria Azatovna Sakhibullina ${ }^{3}$

${ }^{1} \mathrm{PhD}$ in Philological sciences, Associate Professor, Kazan Federal University,

Institute of International Relations, Russian Federation, ${ }^{2}$ Senior teacher, Kazan Federal University, Institute of International Relations, Russian Federation, ${ }^{3} \mathrm{PhD}$ in Philological sciences, Kazan Federal University, Institute of International Relations, Russian Federation, 18 Kremlyovskaya street, Kazan 420008, Russian Federation.

Email: *elenaandreeva7788@mail.ru

Article History: Received on $15^{\text {th }}$ July 2019, Revised on 30 ${ }^{\text {th }}$ August 2019, Published on $18^{\text {th }}$ September 2019

\section{Abstract}

Purpose of the Study: The article discusses values and anti-values in the figurative phraseological units of the Russian and German languages. The object of the research is phraseological units of the Russian and German languages that have similar and specific images. The subject of the research is hedonistic and material-utilitarian values and anti-values contained in the Russian and German figurative phraseological units.

Methodology: The relevance of the study is due to the spiritual needs of modern society. The analysis of phraseological units in the axiological aspect is motivated by the anthropological orientation of modern linguistics where the language is considered in close connection with the consciousness and thinking of a person, their spiritual world, values, and antivalues. The research methods are the following: descriptive method, analysis of lexicographical interpretations, and etymology of the Russian and German phraseological units; the method of component analysis to research the structure of meaning of studied units; the method of conceptual and interpretative analysis.

Results: Hedonistic and material-utilitarian values and anti-values are represented by the Russian and German phraseological units that have similar images in their composition, which is due to the common source of the origin of phraseological units, and specific images associated with the Russian and German cultures.

Application: Research results can be helpful for the German language training and professional activities of translators and linguists.

Keywords: Linguistics, Language, Value, Anti-value, Axiological Phraseological Unit, Similar Image, Specific Image.

\section{INTRODUCTION}

Phraseological units reflect values and traditions of particular people, most clearly in their language. Being specific units of the language, phraseological units contain cultural information about the history and everyday life of people speaking the language (Andreyeva, Mazitova \& Smirnova, 2015; Sakhibullina, Andreyeva \& Nazmieva, 2018).

The category of value occupies a special place within the framework of linguistic and cultural issues. Exploring the relationship of phraseology and culture, Alefirenko points out that the basis of culture is a value principle and a phraseological frame "according to its genetic purpose" and is tied to the "sphere of a culture", since the core of its semantic content is "always a socially significant value perceived by each subject" (Alefirenko, 2008). At the same time, phraseological units are considered as stable signs "in which the value meanings of a culture are embodied" (Kovshova, 2009).

Thus, an axiological component is the most important feature of a phraseological unit motivated by cultural meanings.

\section{METHODS}

The theoretical and methodological base of the research consists of the works of phraseologists in the light of the theory of cognitive linguistics (Babushkin, Vorkachev, Tokarev, Shakhovsky, etc.); works of researchers dedicated to the world value picture in the language (Arutyunova, Babaeva, Bayramova, Baranov, Gulga, Karasik, Komlev et al.); and the linguo-culturo-logical approach in which the value picture of the world is recognized as the core of spiritual culture (Telia, Mokienko, Kovshova and others). At the same time, a methodological position that is the motivation of an idiomatic meaning is carried out precisely in the manner introduced in the internal form of a used phraseological unit.

The research methods are the following: descriptive method, analysis of lexicographical interpretations and etymology of the Russian and German phraseological units; the method of component analysis to research the structure of meaning of studied units; and the method of conceptual and interpretative analysis. 


\section{RESULTS}

The analysis of the figurative phraseological units of the Russian and German languages related to values and anti-values allows us to draw the following conclusions:

1) The basis for the formation of values of figurative axiological phraseological units is their internal form reflecting values and anti-values.

2) When interpreting the figurativeness of axiological phraseological units, images are correlated with myths (biblical, antique), symbols, customs, etc., and the definition of the axiological status of phraseological units.

3) Hedonistic and material-utilitarian values and anti-values are represented by the Russian and German phraseological units having both similar images in their composition, which is caused by a common source of origin of phraseological units and specific images associated with the Russian and German cultures.

\section{DISCUSSIONS}

Values and anti-values in phraseology have already attracted the attention of researchers. Bayramova identifies the following values and anti-values: vital values and anti-values (life and death; health and illness); sacred values and antivalues (homeland and foreign land); hedonistic values and anti-values (happiness and unhappiness); social-utilitarian values and anti-values (labor and unemployment / laziness / rest); material-utilitarian values and anti-values (wealth and poverty); intellectual-cognitive values and anti-values (intelligence and stupidity); moral-ethical values and anti-values (truth and lie); emotional-utilitarian values and anti-values (laughter and crying); and religious values and anti-values (paradise and hell). These values and anti-values are represented by axiologemes, which include "axiologically charged phraseological units" (Bayramova, 2008). opposed to each other and united by the presence of "an axiological vector (positive or negative) that can vary" (Bayramova, 2009).

The concept of an axiologeme - "axiological ideal" - is found in the dissertation research of Zhukov (Zhukov, 2004). The monograph by Mokienko focuses on the images of spoken Russian (Mokienko, 1986). Alefirenko writes about "phraseological gestalt" (Alefirenko, 2008).

Hedonistic and material-utilitarian values and anti-values of figurative phraseological units of the Russian and German languages (based on phraseological dictionaries) are not the subject of the research. Phraseological units representing values have a positive axiological vector or a positive axiological status. Anti-values are represented by phraseological units with a negative axiological status. The axiological status of phraseological units can change.

The axiological status of the Russian and German phraseological units may be associated with their figurativeness. Obviously, figurativeness refers to the anthropocentric sphere of a language since it combines linguistic and cognitive semantics. Kovshova draws attention to this fact: "The image of a phraseological unit becomes the original conductor of a culture thanks to which the convergence of two semiotic systems - culture and language is accomplished" (Kovshova, 2009). Describing figurative phraseological units, Mokienko notes that "the idea of ... images may be vague or completely incorrect"; therefore it is necessary "to reach the true source of each ... image" (Mokienko, 1986).

The figurativeness of phraseological units correlates with their internal form. Some researchers define an internal form as the closest etymological meaning of linguistic units (Potebnya, Gvozdarev). Dobrovolsky believes that the internal form plays the role of a link between two pictures of the world in idiomatics - between literally understood phraseological units and the actual linguistic picture of the world (Dobrovolskij, 1996). In our opinion, the internal form is an associative-shaped representation. As Telia notes, the internal form of a phraseological unit is "both a form of organization of a meaning in accordance with an image-motive and a figurative gestalt structure, which cannot break with this form because it is revealed through it in literal reading" (Teliya, 1996). Kovalevskaya considers the internal form as a reduced image that underlies the origination of the phraseological unit (Kovalevskaya, 2010).

Cultural connotation, characterized by figurative and situational motivation and associated with the worldview of the native speakers, underlies in the internal form of axiological phraseological units.

In interpreting the figurativeness of axiological phraseological units, we correlate the images with myths, symbols, customs, and other signs of national culture. The Russian and German phraseological units that represent values and antivalues have similar or specific images.

The research material is analyzed in the following order: hedonistic values in phraseological units (similar image; specific images); hedonistic anti-values in phraseological units (similar image; specific images); material-utilitarian 
values in phraseological units (similar image; specific images); material-utilitarian anti-values in phraseological units (similar image; specific images).

The hedonistic value of "happiness" (wish of happiness) is represented by the Russian and German phraseological units семь футов под килем, colloq. prof. (fair winds and following seas) and j-m drei Fuß Wasser unterm Kiel wünschen (literally - to wish smb. three feet of water under the keel) - to wish smb. happy swimming. The internal form of the phraseological units reflects the request of a certain number of feet of water under the keel, which contains an image similar to the Russian and German phraseological units (the image of the keel). The specific image is realized through the image of the number: the number семь (seven) and the number drei (три (three)). The number семь (seven) in the Russian phraseological unit is "a number of perfection" (Great Phraseological Dictionary of the Russian Language, 2006) The use of the number drei (three) in the German phraseological unit is connected with the fact that the largest and the most significant ports in Germany are not on the coast of the sea, but in the mouths of shallow rivers and have a small draft of ships. Probably, the wish of only three feet under the keel appeared from here (Maltseva, 2002). At the same time, the number drei (mpu (three)) is a symbol of happiness (Dobrovolskij, 1996).

The hedonistic value "happiness" (luck) is represented by the German phraseological unit $j$-d hat Schwein, colloq. (literally - someone has a pig) with the meaning: "smb. is lucky (not always deserved), happiness smiles at smb.". The semantics of the phraseological unit is motivated by its internal form - an etymological meaning, which determines the positive axiological status of the phraseological unit with a specific image, although the initial expression had the negative meaning. The phraseological unit goes back to the traditions of titling matches and shooters' competitions, where one of the prizes was a pig. The worst shooter received it as a consolation prize. This gain was usually ashamed and a pig was to be carried home hiding from the eyes of others (Maltseva, 2002). However, in the middle ages, a pig became a symbol of good luck and fertility. Wandering students received a live pig with wishes of happiness and health as a payment for agricultural work. A pig could be slaughtered or left to get offspring from it. It was believed that if a person had bread and a piece of meat on the plate in the morning, they were lucky - er hatte Schwein gehabt (that is, they had pork) (Die Geschichte des Sparschweins). Hedonistic anti-value "unhappiness" (a source of misfortunes) is represented by the Russian and German phraseological units ящик Пандоры (Pandora's box) and die Büchse der Pandora / Pandoras (literally - Pandora's jar) meaning 'the source of all sorts of disasters, misfortunes, troubles'. In the internal form of the phraseological unit is enclosed an image that goes back to the poem of Hesiod (VIII-VII centuries BC) "Works and Days". The ancient Greek myth about Pandora (<Greek "gifted by everything") tells that people once lived without knowing the misfortunes, diseases, and old age until Prometheus stole fire from the gods. For this, the angry Zeus sent a beautiful girl Pandora to the Earth to punish Prometheus and all the people. Zeus presented Pandora a beautiful chest before going to the Earth, but warned that she should never look into it. Zeus was convinced that Pandora moved by curiosity would surely open the chest, and all human vices, misfortunes, and misfortunes prepared as a "gift" to humanity would break free from there. Thus, it happened. And only hope remained at the bottom of the box (Birikh, Mokienko \& Stepanova, 1998). The above-mentioned phraseological units have a negative axiological status due to their mythological source of origination. Hedonistic anti-value "unhappiness" (disappointment) is represented by the Russian phraseological unit Вот тебе, бабушка, и Юрьев день! (Here уоu are, grandmother, and St. George's day!), with a specific image. In the internal form of the phraseological unit, disappointment is reflected due to the failure in some unforeseen circumstances. This expression has been in the Russian language since the beginning of the 17th century. The idiom is associated with the abolition of the right to transfer the peasants from one landlord to another, which was already limited, and could occur only a week before St. Yuri's Day (November 26 according to the Old Style) and a week after. This ban meant the complete enslavement of peasants. According to another assumption, the owners paying off with hired workers usually cheated them on the autumn of Yuri's Day after the end of the agricultural work (Zimin 2008). The phraseological unit contains an appeal that reflects its connotative-culturological function. The expression has a negative axiological status.

A German phraseological unit Durchfall haben / erleben, colloq. jokingly (literally - have / survive failure) presents the hedonistic anti-value "unhappiness" (failure, defeat). The unit has the following meanings: 1) do not pass the exam, fail at the exam; 2) lose the election. The expression is an implicit form of the old-fashioned German idiom durch den Korb fallen (literally - fall through the basket). As the researchers note, the phraseological unit is connected with the history of the expression j-m einen Korb geben (literally - to give smb. a basket) relating to the refusal of matchmaking (Walter, 2008). The negative axiological status of the phraseological unit is caused by the image included in its internal form.

The material-utilitarian value "wealth" (the power of money) is reflected in the Russian and German phraseological units поклоняться золотому тельиу (to worship the golden calf) and das goldene Kalb anbeten (literally - to worship the 
golden calf) with the meaning 'to worship the power of money, to be overwhelmed by the thirst for profit'. The image of the phraseological units goes back to the Bible. The Old Testament tells how the Jews returning to their homeland from Egyptian captivity wandered for a long time in the desert and completely lost faith in the quick cease of their wanderings. Then, the priest Aaron ordered to collect from the Jews all the gold jewelry, melt them, and make a golden statue of the calf (bull). The Jews began to offer sacrifices to the golden calf hoping to return home, but the prophet Moses stopped this idolatry (Serov). The Bible says: Он взял их из рук их, и сделал из них литого тельиа, и обделал его резиом. И сказали они: вот бог твой, Израиль, который вывел тебя из земли Египетской! (Исх. 32: 4) - Und er nahm sie von ihren Händen und bildete das Gold in einer Form und machte ein gegossenes Kalb. Und sie sprachen: Das ist dein Gott, Israel, der dich aus Ägyptenland geführt hat! (2. Mose 32: 4) - (And he received them at their hand, and fashioned it with a graving tool, after he had made it a molten calf: and they said, These be thy gods, O Israel, which brought thee up out of the land of Egypt (Exodus 32: 4)).

Researchers point out that the components of phraseological units золотой телеи (the golden calf) and goldene Kalb are a symbol of money, wealth, the power of gold (DUDEN, 2001). Thus, the phraseological units поклоняться золотому тельиу (to worship the golden calf) and das goldene Kalb anbeten reflecting the value of "wealth" have a negative axiological status, which is determined by the semantics of the phraseological units ("thirst of money").

The material-utilitarian value "Wealth" is represented by the Russian phraseological unit как сыр в масле кататься (live off the fat of the land) with the meaning "to live in contentment, in prosperity; live in wealth, in luxury". The internal form of the phraseological unit contains an image that is specific for the Russian language (compared to German). The image of the phraseological unit goes back to the old Russian method of making cheese and storing it in a barrel with butter (Idioms. Aphorisms, the origin of the catch phrases). The phraseological unit contains the comparison and has a positive axiological status symbolizing well-being, satiety, and wealth.

The material-utilitarian value "wealth" (opulence) reflects the German phraseological unit (gut) betucht sein, colloquially (literally - be enveloped in a good cloth) - to be in good material conditions; to be secured, prosperous, wealthy. There is a specific image in the internal form of the phraseological unit. Walter and Mokienko point out referring to the opinion of etymologists that this expression was borrowed from Yiddis, where betuch $(t)$ originally had the meaning of "reliable, safe". The expression gut betucht describes those who live in "absolutely secure" conditions. Most German-speaking people usually associate the expression with "good matter" (gutes Tuch), meaning a person who wears expensive fabrics. Such an understanding is the fruit of a folk etymology (Walter, 2008). The positive axiological status of the phraseological unit is determined by its semantics.

The material-utilitarian anti-value "poverty" (destitution) is reflected in the Russian and German phraseological units беден, как Лазарь (as poor as Lazar) and ein armer Lazarus with the meaning "poor, unhappy person". There is a biblical image in the internal form of the phraseological units with negative axiological status: Был также некоторыи нищий, именем Лазарь, который лежал у ворот его в струпьях и желал напитаться крошками, падаюшими со стола богача, и псы, приходя, лизали струпья его (Лк. 16: 20-21) - Es war aber ein Armer mit Namen Lazarus, der lag vor seiner Tür voll von Geschwüren und begehrte, sich zu sättigen mit dem, was von des Reichen Tisch fiel; dazu kamen auch die Hunde und leckten seine Geschwüre (Lukas 16: 20-21) (And there was a certain beggar named Lazarus, who was laid at his gate, full of sores, and desiring to be fed with the crumbs that fell from the rich man's table; moreover, the dogs came and licked his sores (Luke 16: 20-21)).

The material-utilitarian anti-value "poverty" is represented by the Russian and German phraseological units with specific images. Thus, the Russian phraseological unit избуика на курьих ножках (a hut on fowl's legs) is used to denote a poor home, a fragile structure (Zimin, 2008) that determines the negative axiological status of the phraseological unit. Zimin and Spirin believe that the expression has a real basis. Baba Yaga is an elderly woman who treated people with various herbs. Superstitious people considered Baba Yaga a sorceress and treated her accordingly. The conflicts with the participation of Baba Yaga served as the basis for fairy tales. Sometimes, Baba Yaga was evicted outside the village. She had built a hut somewhere in the woods in the swamp closer to the herbs. The hut was put on the fir-tree stumps because of the dampness. The roots of a spruce looked like paws and the legs of a chicken (Zimin, 2008).

The component избуика (hut) in the phraseological unit has a diminutive meaning nominating a "wooden peasant house" (Ozhegov, 1997). The same diminutive value is carried by the component ножки (legs), which reflects the exterior of the structure: a special kind of foundation when the building is unstable, since the legs are chicken and therefore thin. The chicken's body on thin legs is a figurative basis for designating a hut standing on the trunks of spruce 
trees with bare roots. The internal form of the phraseological unit contains the image of a dilapidated house reflecting the anti-value "poverty" (the dwelling of the poor).

The German phraseological unit blauer Heinrich (literally - blue Heinrich) with the meaning "soup for the poor (thin, watery soup)" represents the anti-value "poverty" (food of the poor). The negative axiological status of the phraseological unit is determined by its specific image. The expression dates back to the reign of the Prussian King Friedrich Wilhelm I. The Director of the Affairs of the Poor was appointed by the king called Henry. Thin soup for the poor was poured into metal bowls, which gave the soup a bluish tint and this was the reason for the origin of a phraseological unit (Maltseva, 2002). Perhaps, thin watery soup was perceived by the poor as food not giving vitality. Probably, the meaning of the phraseological unit blauer Heinrich reflected the negative attitude of the poor to the Director of the Affairs of the Poor - Heinrich. For the internal form of the phraseological unit, the contamination of two images is characteristic: the image associated with the symbolism of blue and the image of Henry.

\section{CONCLUSION}

The analysis of the figurative phraseological units makes it possible to determine the values and anti-values in the Russian and German linguistic culture, which are the reflections of the national mentality and appear in all spheres of people's lives.

The research results can be helpful for German language training and in the professional activities of translators and linguists.

Knowledge of the national mentality of the speakers of the language being studied will allow students of the university to fully implement communicative competence and successfully carry out interpersonal, intercultural, and non-personal communication (Andreyeva, Nazmieva \& Sakhibullina, 2018).

\section{ACKNOWLEDGEMENT}

The work is performed according to the Russian Government Program of Competitive Growth of Kazan Federal University.

\section{REFERENCES}

1. Alefirenko, N.F. (2008). Phraseology and Cognitive Science in the aspect of linguistic postmodernism. Monograph. Belgorod: Izd-vo BelSU. -152 p.

2. Andreyeva, Y., Mazitova, F., Smirnova, M. (2015). Common and specific images of the Russian and German axiological phraseological units in the cultural codes. Journal of Language and Literature, 6(4), 380-384.

3. Andreyeva, Y., Nazmieva, E., Sakhibullina, K. (2018). Axiological Phraseological Units at Foreign Language Lessons at University as a Reflection of National Mentality. The Journal of Social Sciences Research, 308-312.

4. Bayramova, L.K. (2008). Interpretation of phraseological units in dictionaries in the light of Cognitive Science and Axiology. Phraseology and Cognitive Science, Proceedings of the 1st International. Scientific Conference (Belgorod, 4-6 May 2008). In 2 v. Vol.1: Idiomatics and Cognition. Belgorod, 298-302.

5. Bayramova, L.K. (2009). Motherland and death in the axiological paradigm. Philological Sciences, 3, 103-110.

6. Birikh, A.K., Mokienko, V.M., Stepanova, L.I. (1998). Dictionary of Russian Phraseology. Historical and etymological reference . Ed. V.M. Mokienko. - St. Petersburg: "Folio Press". - 700 p.

7. Die Geschichte des Sparschweins. - [Electronic resource]. - Access Mode: http://www.sparkassebgl.de/download/geschichte_sparschwein.pdf

8. Dobrovolskij, D. (1996). Symbole in Sprache und Kultur. Studien zur Phraseologie aus kultursemiotischer Perspektive / D. Dobrovolskij, E. Piirainen. - Bochum. - 485 S.

9. Duden: Duden. (2001). Herkunftswörterbuch. Etymologie der deutschen Sprache [Text] / herausgegeben von der Dudenredaktion. - 3., völlig neu bearbeitete und erweiterte Auflage. Band 7. Mannheim. - 960 S.

10. Great Phraseological Dictionary of the Russian Language. Meaning. Use. Culturological commentary (2006). Main ed. V.N. Teliya, M.: Ast-Press Book. - 784 p.

11. Idioms. Aphorisms, the origin of the catch phrases. - [Electronic resource]. - Access mode: http://www.otrezal.ru/catch-words/544.html

12. Kovalevskaya, L.A. (2010). Internal form as a source of semantic motivation and cultural connotation of phraseological units of the Russian language [Text]. L.A. Kovalevskaya: the author's abstract. ... D. of Philology. Veliky Novgorod. $-21 \mathrm{p}$. 
13. Kovshova, M.L. (2009). Semantics and Pragmatics of phraseological units: linguoculturological aspect. M.L. Kovshova: the author's abstract. ... D. of philology. M.-48 p.

14. Maltseva, D.G. (2002). German-Russian Phraseological Dictionary with linguistic and cultural commentary. Die deutschen Redensarten und Sprichwörter im Spiegel der Geschichte und Kultur: About 1,300 phraseological units. D.G. Maltsev. M.: “Azbukovnik", "Russian dictionaries”. - 350 p.

15. Mokienko, V.M. (1986). Images of the Russian language: Historical, etymological and ethno-linguistic essays of Phraseology. V.M. Mokienko. - L.: Izd-vo Leningr. Un-ta. - 280 p.

16. Nazmieva, E., Andreyeva, Ye. (2018). Foreign Language Teaching Modeling for Students Majoring in Social Studies and Humanities. E. Nazmieva, Ye. Andreyeva, L. Yuzmukhametova .The Journal of Social Sciences Research, 352-357.

17. Ozhegov, S.I. (1997). Dictionary of the Russian Language: 80000 words and phraseological expressions. S.I. Ozhegov, N.Yu. Shvedova . Russian Academy of Sciences. Institute of Russian Language. V.V. Vinogradov, 4th ed., Supplemented. M :: Azbukovnik. -944 p.

18. Sakhibullina, K., Andreyeva, Ye., Nazmieva, E. (2018). Component Parts of Phraseological and Parameological Units with Ornytonym Component in the English, Russian and Tatar Langugages. K. Sakhibullina, Ye. Andreyeva, E. Nazmieva. The Journal of Social Sciences Research, Special Issue 1, 321-324.

19. Serov, V. Encyclopedic Dictionary of Winged Words and Expressions. - [Electronic resource]. - Access Mode: http://www.bibliotekar.ru/encSlov/index.htm

20. Teliya, V.N. (1996). Russian Phraseology. Semantic, pragmatic and linguistic-cultural aspects. V.N. Teliya - M.: Languages of Russian culture. - 191p.

21. Walter, H. (2008). From "A" to "Zwickmühle". Historical and etymological comments on German Phraseology. H. Walter, V.M. Mokienko. - Greifswald: Ernst-Moritz-Arndt-Universität Greifswald, Institut für Fremdsprachenphilologien. - 175 p.

22. Zhukov, K.A. (2004). Linguistic embodiment of the concept of "Labor" in the proverbial picture of the world (based on the Russian and English paremiology). K.A. Zhukov: PhD thesis in Philological Sciences: 10.02.19. Veliky Novgorod. - $156 \mathrm{p}$.

23. Zimin, V.I. (2008). Proverbs and Sayings of the Russian people: great explanatory dictionary / V.I. Zimin, A.S. Spirin. Ed. 4th, ster. Rostov n / D: Phoenix. -590 p. 